\title{
アルミ缶をめぐるトピックスと企業の取組み例 \\ Some topics of aluminum used beverage can (UBC) recycling and remarkable recycling efforts of a can production company group
}

\section{中村 公雄* \\ Kimio NAKAMURA*}

\section{1.はじめに}

本誌は技術誌であるが，アルミ缶の再生処理の技術につい ては，個々の二次合金メーカのノウハウに属すること以外は すでにいろいろなところで紹介されていて，付け加えること はそれほどないので，本稿ではリサイクルの仕組みの問題を 中心に述べる。具体的には，アルミ缶のリサイクル率を上げ る方法の提案，リサイクル率を上げる目的での大掛かりな制 度改革はもはや必要でなく, あえてやってもロスが多いこと， また拡大生産者責任（EPR）の流机に乗った事業者回収は実 質的に不可能で不合理なことを，自治体の収集コストの推 定，生活困窮者の回収実態などのトピックスなどを織込みな がら論じる。

また特集のタイトルが “環境調和技術”であるので，当社 グループのアルミ缶リサイクルの取組みについて述べる。

\section{2.リサイクル社会にあった法制を}

アルミ缶のリサイクル率の推移を図 1 に示す。2001 年度の アルミ䂐のリサイクル率は $82.7 \%$ だと，アルミ午リサイクル 協会（このあと協会之略する）功発表している。昨今の状況 を見ると， 2002 年度は $85 \%$ を超えたかむしれない，と思う。

ところで，このリサイクル率，協会が全力をあげて推定し たもので, 業界団体の発表する数字としてはきわめて精度が

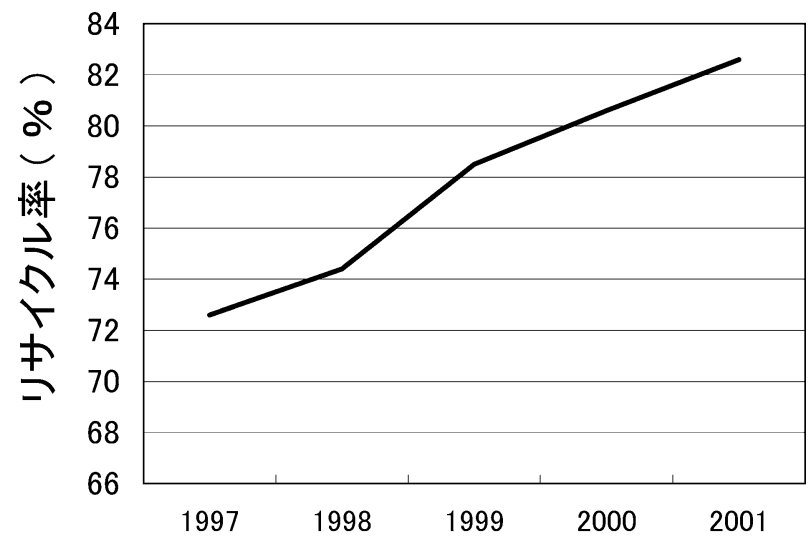

図1 リサイクル率の推移
高いものだと自負するが，さらに精度を高めるためには，国 の支援が必要である。

\section{1 アルミ缶のリサイクル率の出し方}

アルミ缶のリサイクル率の計算は次の通りシンプルである。

$$
\mathrm{R}=\frac{\text { 当年度アルミ镔溶解数量 }}{\text { 当暦年アルミ缶出荷数量 }}
$$

分母のアルミ缶の出荷量は, 協会会員の缶メーカの麼年の 出荷量の推定合計に, 空缶, 実缶（中味が入っている缶）の 輸出入量を，少ないデータから判断して増減を行っている。

分子は, アルミ缶を溶解していると見られる全国各地の工 場に，前年度の溶解量をアンケート方法で調查している。一 部の缶は非溶解のまま使用されるので，それらはそれでカウ ントしている。当然のことであるが, 個々の数字は, 輸入さ 机アルミ缶スクラップやアルミ缶以外のスクラップが混入 されていないか，不自然な点がないかなどを，さまざまな情 報から協会の事務局が吟味して，疑わしいデー夕については 相手に内容を確認している。さらにこの数年間は，抜き取り であるか，監查法人に委託して溶解量が正しく申告されてい るか，相手先の監查を行い正確を期している。溶解量は重量 で把握されることが普通なので，個数からの重量变換は，缶 種ごとの単重の加重平均である。

リサイクルの算出では，分子と分母の間に 3 か月のタイム ラグを設けているが，この期間はアルミ缶が製缶工場から飲 料メ一カに出荷されて消費者を経て溶解されるまでのもので ある。分子と分母にタイムラグを設けないとすれば，理屈と して，最大のリサイクル率は 100 をはさんで上下することに なる。

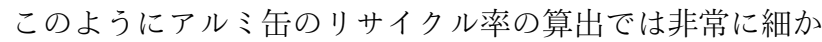
なところまで気を遣っている。

\section{2 アルミ缶のリサイクル率は単純明快}

アルミ缶のリサイクル率の把握は, 缶の市場でのライフが きわめて短時間で輸出入屯比較的少ないから，きわめて明快 である。同じアルミニウムのリサイクル率であ，たとえば建 材のサッシュとなると一度取付けられてから解体されて返っ てくる時間が数十年先，長いあのになると 100 年以上先にな る。こういう製品のリサイクル率をどう表すか。家電製品に

*昭和電工アルミ缶リサイクル推進員会事務局＼cjkstart昭和アルミニゥム缶(森（广 366-0034＼cjkstart深谷市常磐町 56-11)。Syowa aluminum can corporation (56-11 Tokiwacho, Fukaya-shi, Saitama 366-0034).

受理日：平成 15 年 5 月 7 日 
組込まれて輸出されたアルミニウムは, 日本でリサイクルさ れることはない。飲料容器の話に戻って，スチール缶のリサ イクル率は, 飲料缶のほかに缶詰缶や海苔缶, 菓子缶, ペッ トフード缶な゙の総計のリサイクル率だ。ガラスビンの場合 はさらに複雑である。ビン容器に詰められて輸入される食品 だけでも膨大であり，これに国内で製造される種々のビン容 器があり, 現状では数量も重量む把握は困難であろう。その 上にワンウェイビンとリターナブルビンが混在しているのだ。 ビール用のリターナブルビンの寿命は 8 年と言われるが, リ ターナブルビン自体が年々減少している。さらに，色つきの ビンの一部については, 再生後の色のばらつきが大きいため に, リサイクルができないと言われている。そんなことから ガラスビン業界はリサイクル率として, 製造時のリサイクル 材（カレット）使用率を当てている。

容器間競争が激しいので，それぞれの業界が自分のところ はリサイクルの優等生だと言う宣伝を行うが, 表面の数字の 比較は意味がないばかりでなく，危険でさえある。その意味 でアルミ缶愚直なほどにわかりやすい。

業界や製品ごとにリサイクル率の算出方法が異なるのは好 ましくないと, 経済産業省は2001 年度に各関係業界の代表 を含む「資源循環指標調査検討委員会」を設置して, 算出方 法の統一を検討して報告書を作成したが, 結論は現在宙に浮 いていると言われている。

\section{3 リサイクル率を狂わせる要因}

少しであ正確な数字は悲願である。正確を期するアルミ缶 でも, リサイクル率を狂わせる要因はいろいろある。要因だ け列挙しょう。

分母（アルミ缶六欴料市販売本数）の精度。分子：アル ミ䂐スクラップに含まれる異物量。アルミ缶に混入されるエ アゾール缶の量。アルミ缶スクラップの輸出入量。溶解過程 で使用される調整剂（アルミ午以外のアルミ材料など）の量。 また，アルミ缶の再生用途が技術変化などで急に変化し，再 生の新規参入メーカが急増する場合。

話が横道に入るが，アルミ缶の異物について少し触れてお きたい。アルミ缶の溶解歩留まりは一般に 75 85\%くらいと いわれるが，平均すると $78 \%$ 程度になるとされる。数字のレ ンジが大きいのは, 原料となるアルミ缶の品位, 溶解工程, 溶解方法などによるばらつきである。アルミ畋製造工程で 発生するスクラップ（打ち抜き屑）の溶解歩留まりが $95 \%$ 程 度であることからすると，回収した缶に含まれる異物の量は 10〜20\%ということになる。この異物の中身は付着土と水分 が大きく, その他は夾雑物である。異物の付着土とかスチー ル缶などは溶解時に添加元素として働くので, 厳重に除去さ れなければならない。よくたばこの吸い殼の影響についての 質問を受けるが，量的にも多いわけでもないし処理工程で燃 えてしまうので，空き缶に入れられることは不快ではあるが， リサイクル上の問題はない。

\section{4 より正確なリサイクル率のために}

リサイクル率算出の精度をさらに高めるためには午メーカ や協会が努力しなければならない事項と, 関係業界だけでは 力が及ばないことがらがある。

協会は, アルミ午は最終的に溶解されるものとして, 溶解
を行っている事業者等にアンケートを出して, 溶解量を把握 していることは先に述べた。アンケートでの指示事項は, ス クラップ畋の輸入量を除外してほしいということのみである。 このアンケートに答える数字をどう算出するかは回答側に任 されているが，想像するに2つのやり方があると見られる。 第一はアウトプットの量から溶解歩留まりを除することに よって，投入原料量を推定する方法。出てきた数字から，輸 入原料量や “薄め”に使った新塊やアルミ缶以外の量を引け ば，おおよそのところは出る。もう一つの方法は，投入した 原料の合計を出す積上げ式だ。前者の方がたぶん正確であろ う。後者は異物などを含んだ值になりがちだ。

協会のアンケート調査も, 事業者の算出方法について詳細 な手順を示すべきで，漠然と照会する時代は過ぎたであろう。

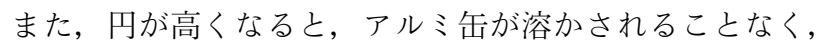
原料として輸出されることがある。2002 年は鉄, ステンレ ス，銅といった金属類のスクラップ，古紙が中国や東南アジ アなどによ゙っと輸出された。アルミスクラップについては全 般的に国内の需要逼迫と高值加輸出された量は多くないと 見られ，さらにアルミ缶については中国が輸入を禁止してい ることもあり，2002 年はほとんどなかったと言われるあの の, 経済情勢の变化いかんでは輸出がいつ急増してもおかし くない。アルミ缶だけの輸出入量の正確な把握は難しいとさ れるが，協会は問屋筋との情報ネットワークを整備してこれ らの情報をきちんと把握する必要がある。

業界の正確なデー夕収集には限度がある。国には統計法が あるが，これがリサイクル社会にマッチしたものになってい ないのが実情だ。リサイクル率の算出に統計法に基づく諸 データを利用することは今のところ不可能である。

飲料容器の母数む, 飲料メーカ（輸入品は輸入業者）が商 品ごとに使用した容器の種類, 容量, 容器の重量, 数量を発 表するように法的ガイドがあればベストである。また，アル ミスクラップ輸出入について, 現在の通関統計は総量が示さ れるだけで，種類ごとの量がわからない。これを細分化して， アルミ缶スクラップの輸出入量がわかるものに変更されるこ とを願う。さらに，二次合金メ一カの溶解量など，リサイク ル率を算出するために必要なむろむろのデー夕を国の指定統 計に組入れることができないか，と思う。

\section{3. リサイクル率にロスを加えること}

この章では，リサイクル率の上限が 100\%ではないことを 説明して, リサイクル率を考えるに当たってはロスの概念を 織込むことを提案したい。

\section{1 リサイクル率 $85 \%$ も目前}

アルミ缶のリサイクル率は, 今後 1,2 年は緩やかに伸び て，まむなくプラトーに達するだろう。まだ伸びると考える 根拠の第 1 は日本ではすべての廃棄物に対するリサイクル, リユースは今後いっそう浸透していく余地があるからで, 他 の商品のリサイクルやリュースが進むにつれ，アルミ缶のリ サイクルむさらに促進されるとみられ，この高值がアルミ缶 のリサイクル率アップに拍車をかけるのは間違いないからだ。 根拠の第 2 は, 2001 年のアルミ缶の末端価格は高い水準で推 移し， 2002 年はさらに高騰した。この高值が当分続くと見ら 


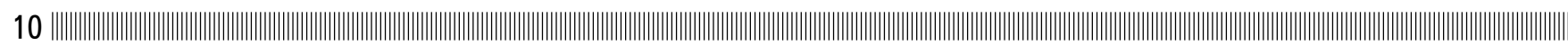

れることだ。国内でアルミニウムスクラップ全体の発生が極 端に減少するなかで，アルミスクラップの需要は自動車や鉄 鋼産業の好調を受けてきわめて旺盛である。(アルミスクラッ プの鉄鋼の関係は，製鋼過程でアルミが脱酸材等として大量 に使われることによる。）しかも，中国という受け皿が整備 されつつある。こういう状況から，この需給アンバランスは アルミ年スクラップにも波及して，高值の取引が続いている。

アルミ缶の高值につられて, 問屋レベルでは他業界からの 転業による参入も少なくない。また回収の末端では, 生活困 窮者の動きが目を引くが，この件は後に述べる。また，環境 教育という面から，教育の現場でのリサイクルへの取組み屯 着実に増える傾向にある。

\section{2 リサイクル率の残りは $17 \%$ はなない}

リサイクル率を $90 \%$ にも100\%にも持っていきたいのは， 関係者の願うところである。

一般論として，リサイクル率は高ければいいというもので はない。何かの理由で需要が急に減退して, 回収量だけが高 い水準で維持される場合はリサイクル率は上がり, 需要が急 伸して回収が追いつかない局面では，リサイクル率は低く出 るので，リサイクル率は販売の伸びと関連付けた見方が必要 である。(アルミ缶の場合は，缶メ一カから出た缶のほとん ぞが 3 か月後には使用済みになって溶解されるので，この点 の留意は必要ないが, 他の容器との比較では要注意である。)

アルミ缶のリサイクルでは, 回収段階から溶解までの段階 で，ある程度のロスが生じることは避けられない。このロス 量を推定する必要がある。ロスはいろいろなところで生じる が，意外にも市町村の分別（リサイクル）センターでの量が 大きいようにも思われる。

家庭系であれ，事業系であれ，市町村が決めたルールに反 した形で排出された資源ごみは，センターにたどりついても 燒却などで処分されてしまう率が高いようである。粗大ゴミ や危険物などに混入されたアルミ缶が，市町村の分別セン ターで再分別されることはほとんどないとみてよい。粗大ゴ ミに混入されたものなら，粗大ゴミ之一緒に破砕されて焼却 にまわされるケースが多い。少し丁寧なところでは破砕くず からの金属の選別回収が行われるが，その精度は低そうであ る。破砕後の選別精度を上げるためには，破砕くずを別途に コンベアに流してアルミの手選別が欠かせないが，手間がか かりすぎることや場所がないなどで，手を加えられることは 少ない。

ビン缶の分別・減容処理工程でも, 設備の設計によっては 意外にロスが増えるようだ。特に廃棄物の受け入れホッパー が, 容器類, 粗大ゴミなどと共通になっている設備は問題が ある。こういう設備は全自動選別方式であることが多いが, 全自動方式は万能であなく, 選別精度も悪いのが実情である。

分別センター内で，屯う少し丁寧なオペレーションがなさ れると，生きてくるアルミ缶の量があるように見受けられる が，現場的にそれを要求するのは難しいとみられる。概して 高機能の自動分別装置を導入しているところは，省人化がう たいものなので，丁寧な仕事はしたくてもできないというの あ無理のないことである。

市町村の分別センターあるいは清掃工場内でのロス分をき
ちんと推定するため調査が必要だろう。

ロスは回収缶の流通過程加も発生する。なんらかの理由 で半端な量のアルミ缶スクラップや分別の方法がないアルミ スクラップは，“こみがら”（=低級ミックススクラップ）と して扱わ机ることがある。“こみがら”として扱われると，二 次合金メーカではアルミ缶としてのリサイクル量にカウント しない。（二次合金メーカではとにかくリサイクルしている のだが)。“こみがら”に含まれるアルミ缶量の実態把握の精 度アップも必要だ。

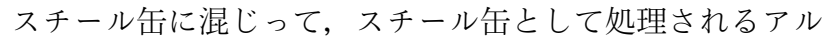
ミ缶の量む，そんなに多くはないかむしれないが，間違いな くある。

リサイクルの施設や流通の過程で消えていく量が仮に $3 \%$ だとすると，リサイクル率の上限は $97 \%$ ということになる。 この数字が $5 \%$ なら $95 \%$ である。現在のリサイクル率が $83 \%$ ならば，残りは $17 \%$ ではないということである。

\section{4. リサイクル率アップのためのソースの問題}

アルミ䂐のリサイクル率の問題は, あと 10 数 \% 程度をど うして達成するかというところまできた。むはやなんでもあ り的な底上げの活動は意味がなく，ターゲットを絞り込んだ 活動が必要であろう。

\section{1 回収ソースの現状と発展の方向}

協会によると, 2001 年に回収されたアルミ缶の総量は 23.5 万トンで，その $66 \%$ は市町村からの回収，13\% が集団回収, $11 \%$ が事業系之言われる公共の場之か商店，自販機などから の回収, $7.7 \%$ がごみステーションからの抜取り, 残りがスー パーやアルミ会社の回収となっている。

ごみステーションからの抜取り，という表現は主語を補え ば何のことかわかるが正確ではない。また，その量も協会は 過小に見ているようだ。ホームレス諸氏や生活困窮者の回収 は前章でむ述べたように幅広く，総量で見ると筆者の独自の 計算では協会推定の倍近い 3 万 5000 トンにもなろう。そう なると市町村に次ぐ回収の主役に踊り出る。

回収ソースの中の $13 \%$ をしめる集団回収の中身は，小中 学校を中心とする学校での回収，障害を持つ人々やその親た ちが作業所で集めているもの，婦人会，老人会，宗教団体な ぞがあり，個人のボランティアもこのカテゴリーに含めてい る。いわゆる学校回収は子供たちの環境教育の意味から多く の学校での取組みが見られるもので, 協会が 7 年ほど前に調 查をしたところ全国のほぼ $1 / 3$ の小学校の参加が確認された。 現在では年 1 回とか 1 学級だけの取組みなどを入れると，む う少し膨らんでいるのではないかと推測される。ただ，その 中身は，児童が中心之は限らず，親たちのみの取組みも少な くない。ボランティア教育という意味からはほど遠い状態だ。 高校，大学の取組みは極端に少なくなる。ある高校の関係者 と話をしていたら，うかつに取組むと，飲酒を勧めることに なりかねない，と言った。逆立ちした論理だと思うが，日本 の教育の一コマである。オーストラリアでは高校生がスー パーの駐車場で，福祉の募金作りにアルミ缶を回収している 姿を見ることもあったが，日本ではオープンなスペースでの 活動の例を知らない。学校㧍よび青少年のボランティア活動 
によるアルミ缶のリサイクルなどは今後むっと広げられても いいと思う。

作業所の取組みは，障害児を持つ親たちが所の運営と彼ら の授産施設建設を目指して必死にアルミ缶を集めているケー スが多い。作業所には“無認可“といわれるプライベートな あのと，福祉法人のように行政の支援を受けた施設があるが， 前者を認可施設にするためには資金で高いハードルが設けら れているために，親たちがその資金作りのためにアルミ缶を 集めているのである。作業所の日々の運営も手弁当なところ に，これである。そういう作業所は全国で 6000 か所以上あ ると言われている。日本の貧しい福祉行政の裏が透けて見え るところだ。法人化された施設でもアルミ罀が集められるが， これは障害者のトレーニングとか授産目的である。

個人は 1995 年ごろを境に層が入れ替わった。それ以前の アルミ缶回収はどちらかというと裕福な人々の，まさにボラ ンティア活動だったが，そういう人々の多くは高齢化したこ と屯あり，退場していった。代わりに登場したのが生活困窮 者たちである。

流通の取組み屯見逃せない。大手のスーパーではイオン， ダイエーなどの取組みが目立ち, 中堅ではカスミの活動が突 出している。滋賀県を中心に酒類ディスカウント店を広く展 開するリカーマウンテンの活動も異色である。彼らの活動は 各社の環境報告書や PR 誌に詳しい。

スーパーなどの小売でのアルミ缶の回収は，自社ブランド 品以外の回収は，客へのサービスであり，ボランティア活動 である。スーパーは自店で付加したスチロールトレーやレジ 袋などに対して再商品化の義務を負っているので, 再商品化 義務を持ったアイテムとボランタリーで収集したアルミ缶な よ゙のアイテムでなんらかのバーターができるような制度が望 ましいと思うのだが，これは協会と流通業界が一体となって 努力する事項であろう。

協会の見解では, 2001 年に回収されないで廃棄されている アルミ缶は 4.8 万 t。その内訳は家庭などからのものが 3.8 万 $\mathrm{t}$ ，事業系廃棄物として埋立てなどで処分されているものが 1 万 $\mathrm{t}$ となっている。この 4.8 万 $\mathrm{t}$ がどこへ行ったのか。一部は 前章で述べたように，リサイクルシステムの中のロスである, 一部は生ごみなどに混ぜられて焼却や埋立てに，一部は農地 や山間部, 海浜, 河川などに捨てられていると見られる。農 地や山間部, 海浜, 河川に放擲されている量は意外に大きい ように見えるがどうだろうか。また市町村の関係者の話では， 住民の協力度が悪い地域もかなり絞られるという。そういう 地域に対して市町村との協力した活動も必要だろう。実態の 調查と的を絞った啓発活動が不可欠である。

事業系から出たものが埋立てに回される理由は, 非アル コール飲料ではアルミ缶の使用比率が少ないために, 回収容 器を扱う零細な事業者が分別を嫌がることにありそうだ。非 アルコール飲料容器では金属缶に限っても，アルミ缶は 4 か ら 5 缶に 1 缶である。自動販売機から出る容器は金属缶以外 に PET 容器, ガラスビン, プラ容器と多様であるから, ア ルミ午の比率はさらに少なくなる。分別してあまったくペイ しないのだ。原料の 3 原則, 量, 品質, 供給の安定性はここ であ当てはまって，少なくとも分別しても売れるだけの量が
必要なのである。この領域でリサイクルを推進するためには, 非アルコール飲料メーカにアルミ午の使用比率を上げてあら う必要がある。その意味で, ボトル缶と称されるビンの形状 をしたアルミ缶の需要が, 非ビール分野を中心に 2000 年度 は 1 億缶だったが， 2002 年度では 11 億缶と急増しているが, これはリサイクルの上からむ好ましいことである。

\section{2 ホームレス諸氏の活動はシステム破壊}

かつて日本がモデルにしてきたアメリカのリサイクル率は 2001 年には $55 \%$ 台に落ちている。この理由については, 日 米では制度の違いが大きいこともあり，軽々なことは言えな いが，ブッシュ政権下の環境問題への取組みの後退と，10 年 にわたって続いてきた好景気によって，アルミ缶回収の大き な担い手だった?ホームレス諸氏が姿を消したことではない か，とも考えてみる。この見方が正しいなら，日本でも回収 をホームレス諸氏への依存が定着すると，景気が回復すれば リサイクル率が落ちることがあるという示唆である。

アルミ䂐のごみステーションからの抜き取りが違法かどう かで, 市町村や住民と抜き取り者の間でしばしばトラブルに なっている。市町村の考え方は, 行政での処理量が減るから 結構，という立場から，アルミ缶は貴重な財源，抜き取りは 困るというところまで，ばらばらである。

彼らの活動がどの程度かを知るデータがある。表 1 に大阪 市が発表したアルミ缶の回収量のデー夕を示すが，これを分 析すると，市が 2001 年に収集したアルミ缶は発生量の $7 \%$ 弱 に過ぎない。残りのほとんどをホームレス諸氏などが持って いったと見てよいであろう。（筆者の推定では，2001 年度の 大阪市でのアルミ缶の発生量は5 700 トンである。回収率が 全国平均なら，市内で回収される量は 4000 トン，そのうち 行政が回収しているのは 370 トン，すなわち $9 \%$ 強にすぎな い。発生量から見ると，6.5\%になる。）

ホームレス諸氏と住民や行政とのトラブルは，住民の彼ら の存在に対する嫌悪感をベースに，市町村が自治会などに分 別収集のためのインセンティブをアルミ缶の回収量に応じて 出しているところでは, 分配金が少なくなること, 少し細か なことでは，抜き取り行為で音が出るとかステーションでの ごみの散乱がひどくなることなどさまざまである。違法だか ら取締まれという声もある。

ごみステーションからの抜き取りは違法という根拠は，家 庭からごみステーションに出されたところで, 所有権が市町 村に移っているということだが，その論理には無理があると 筆者は考えている。排出者はすでに所有権を放棄しているの で委譲はありえず, ごみステーションでは無所有物になって いると見るのが常識的かと思われる。

ホームレス諸氏の活動は, リサイクル率のアップにいくら かは貢献しているであろうけれど，大局的な立場に立てば,

\section{表 1 大阪市のアルミ缶の回収量推移（大阪市資料）} 単位トン

1997 年度 1998 年度 1999 年度 2000 年度 2001 年度

$\begin{array}{lllll}1,940 & 1,228 & 667 & 531 & 370\end{array}$


リサイクルを推進する側からは実のところありがたくない。 彼らの活動は既成システムの破壊である面が強く，また健全 なリサイクル活動に暗い色をつけてしまう，その意味から屯 迷惑な存在である。彼らの活動が大きくなれば，学校回収な どの集団回収は低調になりかねない。

また，アルミ缶のリサイクルの話と，彼らの救済の話を混 同すべきではない。まして，彼らを回収の柱と位置づけるこ とはできない。彼らは景気回復とともに去っていくからだ。 彼らが去った後, リサイクルシステムの再構築は意外に容易 ではない。（誤解ないように言うと，筆者は彼らの活動を取 締まれ，と主張しているのではない。彼らを生み出す社会そ のものが問題なのである。)

\section{5. 制度改革は必要か}

リサイクル率を上げるためにデポジット制度を導入すべし と言う論議が繰返し出てくる。しかし，リサイクル率の向上 だけなら，屯はや大幅な制度改革は必要ない。制度改革の主 張の中にはリサイクルコストを全面的に生産者に負担させよ うという意図がある。事業者はそのコストを負担できるの か?

\section{1 市町村による回収コスト}

情報公開制度ができたが，我々が知りたい情報を手に入れ ることは容易ではない。市町村の再生資源の回収コストもそ の一つである。ある数字が手に入っても，その数字の評価は さらに難しい。市町村のコストを考える場合，収集や分別， 減容処理を市の職員の手で行うのか, 外注に出しているのか, 機器の減価償却費を含んでいるのかいないのか，間接の人件 費を計算に入れているか, 啓発機材や活動費を織込んでいる のかどうかなどで，数字が大きく異なってくる。しかし，こ れらのことは殆どベールに包まれている。

名古屋市は 2000 年度の空き缶（アルミ缶とスチール䂐） の売却益を差し引いた収集コストを 102 円 $/ \mathrm{kg}$ と発表してい る*1。収集量は，非公式な数字であるが，アルミ缶が 1500 卜 ン，スチール罀が 7900 トンといわれている。

名古屋市のアルミ午スクラップの売却価格を 80 円 $/ \mathrm{kg}$, ス チール缽を 2 円 $/ \mathrm{kg}$ と仮定すると，売却前の収集コストを推 定することができる。結果は 10 億 9500 万円，116 円/kgに なる。

$$
\frac{a A+s S}{A+S}=116
$$

$a$ : アルミの回収・処理コスト $A$ : アルミ缶の回収重量 $s$ : スチール缶の回収・処理コスト $S:$ スチール缶の回収重 量

ここから，アルミ䂐，スチール缶れぞれの回収コストが 導けそうであるが，ことはそう単純ではない。体積の要素を
考慮しなければならない。アルミ缶 $350 \mathrm{ml}$ が主力で，ス チール缶は $190 \mathrm{ml}$ の細径缶が主流である。

筆者が埼玉県某市のリサイクリングセンターに集められた スチール罀と, 関東のスーパーマーケットに持ち込まれたア ルミ缶を実測したところ，アルミ缶の 1 缶当たりの平均単重 は $16 \mathrm{~g} ，$ スチール罀は約 $34 \mathrm{~g}$ で，アルミ缶のかさ比重は 0.03 であり，スチール缶のそれは 0.09 であった。また，アルミ缶 は変形しているあのが多く，変形による平均の体積減少率は $26 \%$ だった*2。

実際の回収の現場では，アルミ缶は 2 トン車に $300 \mathrm{~kg}$ 程度 しか載らないが，スチール缶だけなら 1 トンの積載が可能で ある。回収車を運行するコストだけでは，アルミ缶のキロ当 たりコストはスチール䂐に比べて 3 倍ほど高いことになる。 減容処理のコストは両方ともほぼ同じであろうから， $a=3 s$ と いう事にはならない。直感的には $a=1.2 s$ あたりではないかと いう気がするが，このあたりは現場での精査が必要である。 また，できれば企業が行う積上げ方式の原価計算による検証 がほしいところである。

$a=1.2 s$ の場合は，アルミ缶の収集・処理費用は 135 円 $/ \mathrm{kg}$, スチール缶は 112 円 $/ \mathrm{kg}$ 程度になる。売却費を引くと, アル ミ䂐が 55 円/ $\mathrm{kg}$, スチール缶が 110 円/ $\mathrm{kg}$ の行政の持ち出し

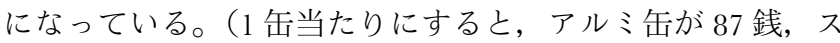
チール䂐が 3.7 円の負担になる。)

関東の 40 万都市の缶の収集・減容費用の概算を，関係者 からの聞取りをもとに筆者が積上げ方式ではじいてみたとこ ろ，1 缶 3 円程度になった。ここはすべて業者委託である。

自治体の飲料容器の収集コストについては, 廃棄物学会 消費者市民部会の調査として，西ヶ谷信雄氏が紹介している もの*3, 安田八十五氏が(社)日本アルミニウム協会と共同で, 115 市の飲料容器の種類ごとのリサイクル費用を調べたも の*4 があるが, 容器間の比較に重点を置いたために, 非現実 的なモデルに基づいた計算になっているとか，計算の過程で 可積載量が考慮されていないとかで，実際とはかなりかけ離 れたものになっている。

市収集のアルミ缶の売却価格は相場で大きく変動している が，再資源品の価格から逆算して 80 円から 100 円 $/ \mathrm{kg}$ が適正 価格とすれば，その価格では市の収集・処理コストを埋める ことはできず，市の持ち出しとなり，その分は税金による処 理である。

市町村は収集した再資源は，容器包装リサイクル法で，再 商品化の品質向上のための分別や圧縮，水洗，保管を行うこ とになっているが，このための施設や倉庫維持の費用負担が 大きいことが指摘されている。事実, 都市部での分別セン ターの建設には巨額の費用をかける例が相次いでいる。高額 な施設はランニングコストも大きくなることが多い。

30 万都市で缶の分別と圧縮の専用設備なら，建物は別にし

*1 名古屋市第 3 次一般廃棄物基本計画

*2 2003 年 2 月に埼玉県の某大都市の籠回収によって分別センターで集められたスチール午 306 個，茨城県の中堅スーパーの店頭回収で集め られたアルミ缶 435 個から分析した。数回の分析が望ましいが，1 回だけのデータである。缶の構成は夏と冬では異なるとされるが，こ こでは冬のデータのみである。

*3西ヶ谷信雄＼cjkstart再商品化費用の事業者之市町村の負担比較月間廃棄物 20018 月号 pp23-29

*4(社)日本アルミニウム協会（安田八十五）飲料容器のリサイクル費用の容器間比較(社)日本アルミニウム協会 2001 
て 5000 万円もあれば必要十分なものができる。アウトプッ トされるブロック状のプレス品は非常に高品位のものだ。異 物の選別を人手で行うところがミソである。

ビン年, PET ボトルなどの混合回収物やさらには粗大ゴ ミ あ一緒にホッパーに投入して，後は機械が自動処理する設備 の導入が盛んだ。しかし残念なことにこの設備から出てくる 資源は品位が悪く, 溶解時の歩留まりがよくない。アルミ缶 を圧縮したブロックには木屑, ペットボトル, カレット（ガ ラスビン屑)，ゴム，プラスティックなどさまざまの夾雑物 がある。異物が多いブロック状のアルミ缶プレス品は, 用途 が限られるから価格も安い。この自動分別方式の精度の悪さ がアルミ缶よりもっと深刻なのはガラスビンと言われている が，それについてはここではカットしたい。分別精度は人に 勝るものはない, というのが現場の声である。

全自動設備は複雑で, 数億円あるいは 10 億円を超えるも のああるようだ。だが，非常に精緻に計算され，コンパクト にま之められた設備は, 何かの理由でその中の 1 つのコン ポーネントを交換する必要がでても, 実質的に不可能とか, 大々的な工事になるとか, 改良や拡張することもきわめて難 しいケースが多い上うに見受けられる。いろんな理由で施設 費も工事費も莫大, 維持費も莫大ということになるケースが 多いが, 必要以上の設備や, 時代の変化に対応していくこと ができない設備でリサイクルのコストが押し上げられること は好ましくない。

\section{2 容器リサイクル法への批判}

容器包装リサイクル法は, リサイクルを 2 つのステージに 分けており, 前段は収集であり, 後段は再商品化の義務であ る。

アルミ缶はスチール缶, 牛乳パックと並んで, 市中でリサ イクルが経済合理的にうまくいっているからという理由で, 容器包装リサイクル法の再商品化義務から免除されている。 しばしば誤解があるが，これらの 3 アイテムは再商品化の手 続きの一部が免除されているだけで, 容器包装リサイクル法 の対象外ではない。収集は市町村の責務になっている。

容器包装リサイクル法に対する批判はいろいろあるが，そ の中の最大のものが市町村の財政負担が大きすぎるというこ とと再商品化段階での“ただ乗り”である。

市町村には負担が大きいとの不満が強いが，収集コストが 市町村の負担になっているということ。これを裏返すと, 拡 大生産者責任のあり方が不徹底だということである。

“ただ乗り”というのは法で“容器包装”と定義される製 品を作るか使用している一定規模以上の企業は, その再商品 化義務を遂行するにあたっては，自社で再商品化するか，そ れができないならば財)日本容器包装リサイクル協会に, 生産 量または使用量に応じて決められた料金を払って，再商品化 を委託することになっている。しかし，その料金を払わなく ても再商品化が進む仕組みであることから，料金を払ってい ない企業が多いという指摘なのだが，これはアルミ缶とは直 接関係がないので, 略する。

その他の批判は, 一定規模以上のオフィスや商業施設から 出るいわゆる事業系の容器包装廃棄物は法の対象外であり,
この扱いが中途半端だとの指摘もある。また，市町村の中に は, 容器包装リサイクル法は, 廃棄物発生の抑制が働かず, 発生量拡大の免罪符だと言う批判がある。増えた分だけ自治 体の負荷が増えるというわけだ。

重要なことは，容器包装リサイクル法は EPR（拡大生産者 責任）を重視する方向にいずれ改定されることになりそうだ が，そのときアルミ午だけが例外扱いにされるとは考えにく い, ということである。

\section{3 事業者回収は意味がない}

いろんなことで公から民への移行が，規制緩和のもとで進 められつつあるが, この流れには行政の事業にはコスト感覚 が薄い, という言外の非難が含まれている。一般廃棄物の収 集の完全民営化の動きはいまのところない。これを実施する ためには，ごみ収集の有料化が先行する。

再資源化物の回収, 再商品化については，拡大生産者責任 （EPR）強化の流れの中で事業者の責務または義務という方 向が強まりつつある。しかし, 事業者のコストは最終的には 消費者が負担することになる。

アルミ缶のみを事業者がごみステーションから直接回収す ることが採算的に可能か，また総合的に考えてメリットがあ るか。容器の種類が多い現状では結論的にはNOである。

前章で試みた自治体の回収コストの推定では，アルミ缶は むう一つ努力すれば，採算ベースに乗りそうだが，それはす でに事業のインフラがあることに加えて，スチール缶とあわ せて回収されているからで，アルミ缶だけを切離せばそうは ならない。

全国規模で収集ステーションや処理基地を新たに設けるこ とは市町村との二重投資であり，かつ膨大なコストがかかり， ナンセンスである。収集は既存のスクラップ業者に委託すれ ばできそうにも思われるが，業者の規模，業者間の利害など ああり，その調整と管理は考えるほどには易しいことではな い。

また，実際の回収作業では，道路事情等で回収車が所定の 時間内に回ることができるステーションの数は限られている。 ステーションに 1 回に出される量む増えるわけではない。週 1 回の回収を 2 週間に 1 回にすれば，効率的に見えるが，住 民にとってはサービス低下であり，大都市部では各家庭に保 管スペースがないのが実情だ。

アルミ缶は現今のような社会状況ではステーションからの 抜き取りが多いが，回収作業は抜き取りがあることを前提に 仕事を組立てるわけにはいかない。ステーションにものがあ ろうともなかろうと全ステーションの巡回が必要である。

容器の種類ごとに, 容器メーカが巡回回収することは, 合 計の投入車両も人員も増え，トラックの消費燃料や排ガスも 増えることを意味する。地方に行けば, 容器全体の混合回収 が一番経済的であるのは明らかだ。したがって，アルミ缶の みの事業者回収はありえず，ドイッの DSD 方式のように関 係業界がまとまって事業展開をする以外にはないということ になる。事業者が全国津々浦々まで回収に回るようなことは, 経済性から見ると，管理機構だけ膨張して，殆ど意味をもた ないであろう。効率も今よりあよくなる保証はない。それで も, 仮にやるとした場合, 最初は市町村のコストより安くと 


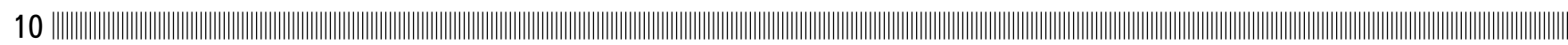

いうことで，スリムな組織でスタートするかもしれないが, 時間が経ってくると，無理は通じず，組織は肥大すると考え ておくべきである。また現在の市町村の職員や委託業者との 関係，施設をどうするのかむよく考える必要がある。海外に あ，フランスのエコアンバラージュ方式，韓国の課徴金方式 など参考になる事例もないではないが，日本は日本の実情に 合わせた，独自の方式を考えるべきであろう。一部の運動家 から声高に聞こえるものには意外之独創性がないのが残念だ。 選択肢には現状の手直しも含まれると思う。

\section{4 百害あって何の利もないデポジット制度}

リユースまたはリサイクルを目的に製品に預かり金（デポ ジット）を上乗せて販売し，回収時点で預かり金を払い戻す 制度をデポジット制度というが, 飲料容器のリサイクルに, デポジット制度を取入れるべきだ，という主張が根強くある。 この理由にはデポジット制度を導入すればリサイクル率が高 くなるというむのと, 容器の回収コストをこの制度を通じて 市町村から事業者に移転させよ，という2つがある。さらに デポジット制度をリターナブルビン保護とからませた論議も ある。筆者は日本でのデポジット制度の導入は，あっとも実 現が困難でかつコストが高く，論議にも值しないものだと 思っている。

ドイッはリターナブルビン保護の視点から，2003 年 1 月か らワンウェイ容器に対してデポジット制度を全土で導入した。 本格的になるのは 10 月からである。この制度については中 祖利雄氏の紹介が現時点では最も新しい*1。また, インター ネットでも最新の状況を知ることができる*2。

少し回り道になるが, リターナブル容器復活の主張につい てコメントしておきたい。リターナブルシステムをうまく機 能させるためには, 消費者と飲料メ一カとの空間的な距離が 小さいことが重要であるが，日本の大手の飲料メ一力は工場 を集約する方向にあり，消費者之工場間の距離は開く一方で ある。ビールを例にしても小規模なメ一カが林立するドイッ とは対照的である。消費者とメ一力の空間的距離が遠くなる と, 複雑な逆流通のネットワークを作る必要があり, これに は膨大なコストがかかるものと見られ，非現実的である。

デポジット制度にはいろんな方式があるが，どんな方式で あろうとあ日本ではメリットがないことは同じである。筆者 がデポジット制度に非常に懐疑的な理由を，以下にまとめて 打きたい。

第 1 は，アルミ年のリサイクル率は 2 章でも述べたように, あと $10 \%$ 余りしか伸ばす余地がない。そのために大々的な制 度改革を行うのは，費用対効果の上で，無意味である。

第 2 は，市町村が財政的に苦しくなる中で，ごみ収集の有 料化之同時に容器または飲料メーカへのコスト転嫁のための 制度導入の主張がある。市町村のコスト増は深刻な問題だ が，仮にこれを事業者に全部かぶせるなら，飲料事業そのも のがなりたたなくなる恐れがある。飲料容器については，民 間回収む市町村に依存しない限り, 単独では無理であろうこ とは先に述べた。
一方で現在行政の回収システムが，コストには問題がある あのの，うまく機能していることがある。行政のコストを メ一カが部分的にも負担する必要があるなら，それには別の 考え方を導入するほうが，合理的であろう。飲料容器回収の ために仮に民間で新組織を作ったとしても，行政のごみ収集 コストはさほど減らないだろう。行政は仕事が減った分だけ 関係の職員を減らすことが容易でないからだ。ということは， 新制度の導入はマクロで見た場合, 廃栽物の収集と中間処理 の総費用は現在よりもはるかに膨らむことになる。

第 3 はデポジット制度では預かり金だけでも大きな金が動 き，それには利権が発生する。預かり金の管理方法は実に煩 雑で, 今の消費税以上であることは容易に想像がっくことで ある。

第 4 はこの制度は全国的な組織になるため, 組織の運営 費，管理費で莫大な費用がかかるのは必至である。

制度の運営に未返還金を当てるという考えもあるが，リサ イクル率が高ければ，未返還金だけではシステムの運営費む 出ないことになる。運営費を誰がどんな割合で負担すること になるかが問題だが, 飲料之容器メ一カが持つことになれば, いずれ製品の価格に跳衫返すとしても，業界として負担に耐 えることができないこともあろう。大手の飲料メ一カのみが 有利になり，中小は淘汰されることになる。そういうことが 国民にとっていいことかどうか。

第 5 は日本の都市の過密，土地価格などを考えると，バイ バックセンターの設置は，かなり難しいということである。 回収された容器には飲み残しの液があり，相当の臭気やまた 糖分に寄ってくる虫も多い。保管倉庫は臭気之残液に污さ れ，それへの対策をとらないなら，周囲に拡散する。保管庫 の臭気対策を完璧にしようとすれば，大がかりな設備になり， 設備費用之維持費用がかさむのは都市部のリサイクリングセ ンターの例からも明らかである。

さらに一缶は軽いが，集まると重量物であり，ハンドリン グはかなりの労働である。回収センターを機械化すると，非 常に大きな面積を要する。センターの中でフォークリフトを 走らせるとすると，どういうことになるか，ご想像願いたい。

また，世間では小売を通しての逆流通，あるいはコンビニ などで回収してそれを宅急便などで集める方法があるのでは ないかという意見もあるが, 実際は難しい。流通の実態や小 売業の実態からすると, 回収がどこの小売店でもできるとい うものではない。宅急便などの組合せは，缶が污れているこ とや臭気もあるなどのことを考えると，他の配達品と積合せ はできない。

また，都心に容器の種類ごとにバイバックセンターなどを 設けるなら，その数はいくつ必要であろうか。小中学校の数 は全国で 3 万 9000 校，郵便局数は約 2 万 5000 である。そし てそこにアクセスするトラックの量や，環境負荷むよく考え るべきである。これはコストの問題以前である。

第 6 はデポジット制度は，高価でリサイクルできるアルミ 缶にとっては有利な制度だと言う説もあるが，これは制度の

\footnotetext{
*1 中祖利雄 ドイッ今年 1 月 1 日をもって包装政令のワンウェイ飲料容器デポジット規定が発動 月間廃棄物 2003 年 3 月号

*2 環境ニュース http://www.eic.or.jp
} 
作り方いかんであり，必ずしあ正しくない。いずれにしろ， デポジット制度は事業者に多大な費用負担を迫るむのになる ことは，間違いない。

\section{6. 昭和電エグループの回収活動}

\section{1 歴史}

昭和電工グループのアルミ缶リサイクル活動は，旧昭和ア ルミニウム株時代の 1981 年ごろに始まっている。同社がア ルミ缶の製造を開始したのが 1971 年だから，10 年後になる。 アルミ缶の PR, 企業の地域活動の一環として, 工場周辺の 住民を対象に専用トラックによる巡回活動を始めたのである。 1990 年になって，環境問題の高まりを先取りする形で，社 員参加のリサイクル活動が提唱され，社員からの有償回収活 動が始まることになった。また同時に事業所近隣のボラン ティアなどからの回収活動も格段に強化することにして，堺， 小山に続いて彦根, 東京, 大阪という都心部にも回収拠点を 広げた。また事業所がない千葉県の八千代市で実験的にアル ミ缶専用のバイバックセンターを設けた。このセンターはカ リフォルニア州のデポジット方式を試してみる意味があった。

始好之，堰を切ったように大量のアルミ缶が社内に持ち 込まれた。大メディアも続々と報道し，近隣の商店や関係会 社を巻込んで活動は盛上がった。地域と事業所との親密感も 格段に高まった。回収缶の処理のために, 堺, 彦根, 小山の 事業所にはアルミ缶専用の大型プレス機を設けた。

活動が旧昭和アルミグループ全体に及んでいるために, 主 な関係会社で昭和アルミのトップを長とする“アルミ缶りサ イクル推進協議会”を作り, 活動のプロモーションとコント ロールを行った。

この活動は当時の通産省の後押しもあり, 活動は同業他社 にも広がっていった。昭和電工グループのスカイアルミニウ ム(㑣)，昭和軽合金(㑣も同様な活動を，規模こそ違え，そのと きに開始し，現在にいたっている。

1995 年になって昭和アルミニウム缶獭は(㑣昭和アルミ缶リ サイクリングセンターを設立して，回収缶をアルミ缶の原料 に使うことにした。缶の原料となると，従来の回収量では間 に合わず，業者からの大量の缶の購入が必要になった。昭和 軽合金はダイキャスト用に大量のアルミ缶を使い始めた。

\section{2 現在}

2001 年昭和アルミニウムは昭和電工と合併したが，活動は 殆どそのままの形で昭和電工に引き継がれた。推進母体は, “昭和電工アルミ缶リサイクル推進委員会”となり, 副社長 直属のリスポンシブルケア委員会の下に入ることになった。 昭和電工㑣全グループでの活動は 2002 年から軌道に乗り始 めているところである。事業所近郊のアルミ缶回収活動は, 行動半径を $40 \mathrm{~km}$ 程度まで拡大している。

千葉のバイバックセンターは月 5 トン程度の回収が長い間 続いたが，4回移転を繰返しながら現在では 30 トンまで膨ら んでいる。大口の発生元には回収車を派遣している。

社員回収については, 開始した 1990 年と今では社会状況 の変化で, その意味むかなり変わってきており, 現在は 2 点 をアピールしている。第 1 は，環境活動に自分から参加する 意味，第 2 はグループ社員としてのアルミ缶事業支援である。

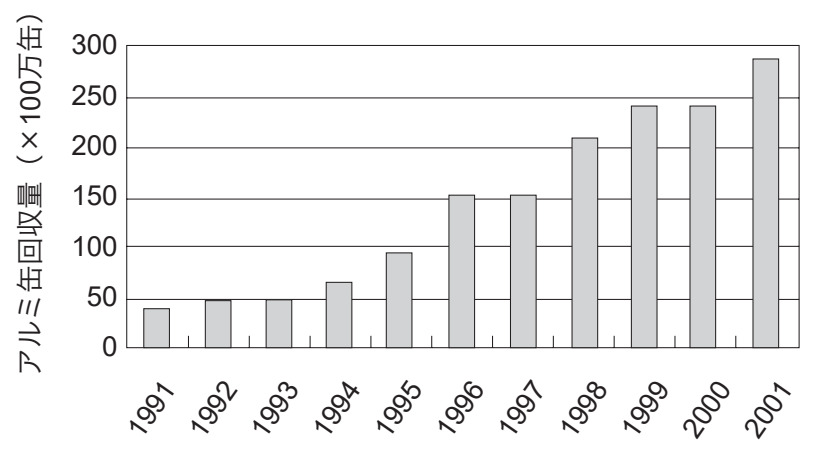

図 2 昭和電工グループの社員㧍よび事業所近隣からの アルミ缶回収量

環境問題は，人任せということでは真の意味での解決にはな らない，アルミ缶を切り口にして自分で何ができ，自分がど うコミットしていくか考える手がかりという意味だ。また会 社員は地域とのつながりが希薄になりがちだが，こういう形 で近隣やコミュニティとのかかわりを深めて欲しい，という 願いあある。さらに会社としては, 環境活動に対する誰の目 にも見える形での企業メッセージの発信である（図2）。

昭和電工の関係会社の中には, (侏昭和アルミ缶リサイクリ ングセンター, 昭和軽合金(株), スカイアルミニウム株), 昭光 通商(株がアルミ缶の再生事業にかかわっている。商社の昭光 通商を除いて， 3 社がアルミ缶を再利用した量は年々増えて いる。

ただし，筆者個人の意見だが，アルミ缶のリサイクルで Can-to-Can に固執するのは間違いだと思っている。回収され たアルミ缶はそのときのもっとも経済合理的な用途に使われ るのがベストだと確信している。

昭和電工グループのアルミ缶リサイクルに対する取組みに ついては, 同社のホームページにも詳しく揭載しているので, そちらをご参照いただければ幸いである。

\section{7. おわりに}

アルミ缶のリサイクルの現場で経験したり，見たり聞いた りしたことを踏まえ, 稿をまとめた。飲料容器のリサイクル についてはいろんな方がさまざまな意見や提案を出され，そ の中にはデポジットの法制化への強い運動を行っている団体 あある。しかし，たとえばデポジット制度を論じるにも，推 進論者は現状を知らなさ過ぎる，と思うことがしばしばであ る。都心の飯田橋で, 近隣のご協力ああって, アルミ缶の回 収活動をほぼ 10 年続けたが, こういう地での活動の困難さ を打知りいただければ，デポジット制度の提唱などそう簡単 に言えないと思う。

アルミ缶のリサイクルを論じるにも廃棄物政策全体の中に 位置付けた見方が必要だし，また制度を考える場合は国民の 総コストの視点が不可欠である。すべて全体の視点を欠くと， 思わ如落とし穴が待っている。このことを強調しておきたい。

なお，この原稿をまとめたのは 3 月なので，この稿が捄手 元に届く頃には 2002 年度アルミ缶のリサイクル率が発表さ れているので，新しいリサイクル率に読み替えていただきた い。 